\title{
ANOMALOUS AMS RADIOCARBON AGES FOR FORAMINIFERA FROM HIGH-DEPOSITION-RATE OCEAN SEDIMENTS
}

\author{
WALLACE S BROECKER*, SUSAN TRUMBORE***, \\ GEORGES BONANI**, WILLY WÖLFLI** and MILLIE KLAS*
}

ABSTRACT. Radiocarbon ages on handpicked foraminifera from deep-sea cores are revealing that areas of rapid sediment accumulation are in some cases subject to hiatuses, reworking and perhaps secondary calcite deposition. We present here an extreme example of the impacts of such disturbances. The message is that if precise chronologies or meaningful benthic planktic age differences are to be obtained, then it is essential to document the reliability of radiocarbon ages by making both comparisons between coexisting species of planktonic foraminifera and detailed down-core sequences of measurements.

\section{INTRODUCTION}

In a previously published paper (Broecker et al, 1988) we document that systematic differences exist between ${ }^{14} \mathrm{C}$ ages for $G$ sacculifera and $P$ obliquiloculata from sediments in the South China Sea. In that paper, a case is made against three of the obvious causes for such differences, $i e$, calcification depth, abundance changes and dissolution effects. In an attempt to come to grips with this problem, we made measurements on planktonic foraminifera pairs from two other cores from this region: V24-135 from the Sulu Sea $\left(7^{\circ} 21^{\prime} \mathrm{N}, 120^{\circ} 21^{\prime} \mathrm{E}, 4276 \mathrm{~m}\right)$ and V33-88 from the western Pacific Ocean $\left(2^{\circ} 42^{\prime} \mathrm{N}, 127^{\circ} 50^{\prime} \mathrm{E}, 3237 \mathrm{~m}\right)$. Both cores have sufficiently high sedimentation rates $\left(\simeq 10 \mathrm{~cm} / 10^{3} \mathrm{yr}\right)$ so that impacts associated with bioturbation are minimized.

The results listed in Tables 1 and 2 were obtained on targets prepared by the cobalt catalyzed reduction method (Vogel et al, 1987) and measured by accelerator mass spectrometry (AMS) at the ETH/AMS Facility in Zürich, Switzerland. No correction for the air-sea $\Delta^{14} \mathrm{C}$ difference has been made. To do this, 400 years should be subtracted.

\section{SULU SEA CORE V24-135}

We chose core V24-135 because carbon and oxygen isotope records are available (Lindsley et al, 1985) allowing us to select glacial age horizons. Although nearby core V28-322 $\left(7^{\circ} 58^{\prime} \mathrm{N}, 120^{\circ} 11^{\prime} \mathrm{E}, 4102 \mathrm{~m}\right)$ is reported to contain mud turbidites, no mention is made of similar layers in V24-135 (Lindsley et al, 1985). Nor could we find evidence for such layers in our examination of the core.

The results (see Table 1) came as such a shock that we immediately repicked and redated the two samples from the 101-102cm horizon. As agreement with the first set was achieved, we are convinced that the differences are geological rather than experimental in origin.

It is clear that neither abundance changes nor growth effects can account for the bizarre pattern of ages. As the foram shells are well preserved and deposition rate is high, we doubt whether dissolution is the villain, especially in a core with such a high deposition rate.

One way to look at the results is to assume the process creating the age 10965

*Lamont-Doherty Geological Observatory of Columbia University Palisades, New York

**Institut fur Mittelenergiephysik, ETH Hönggerberg, 8093 Zürich, Switzerland 
TABLE 1

AMS ${ }^{14} \mathrm{C}$ ages for handpicked planktonic foraminifera from Sulu Sea core V24-135 (7 $\left.21^{\prime} \mathrm{N}, 120^{\circ} 21^{\prime} \mathrm{E}, 4276 \mathrm{~m}\right)$

\begin{tabular}{|c|c|c|c|c|}
\hline $\begin{array}{l}\text { Depth } \\
(\mathrm{cm})\end{array}$ & $\begin{array}{c}\text { Coarse fraction } \\
(\%)\end{array}$ & Species & $\begin{array}{c}\text { Abundance } \\
\text { (mg/gm) }\end{array}$ & $\begin{array}{c}{ }^{14} \mathrm{C} \text { age } \\
(y r)\end{array}$ \\
\hline $101-102$ & 22.9 & $\begin{array}{l}\text { G sacculifera } \\
P \text { obliquiloculata }\end{array}$ & 13.6 & $\begin{array}{l}14,010 \pm 160 \\
14,550 \pm 130 \\
10,660 \pm 130 \\
10,390 \pm 100\end{array}$ \\
\hline $110-111$ & 31.3 & $\begin{array}{l}\text { G sacculifera } \\
P \text { obliquiloculata }\end{array}$ & $\begin{array}{l}6.2 \\
1.2\end{array}$ & $\begin{array}{l}17,870 \pm 150 \\
16,320 \pm 150\end{array}$ \\
\hline $119-120$ & 5.6 & $\begin{array}{l}\text { G sacculifera } \\
P \text { obliquiloculata }\end{array}$ & $\begin{array}{l}1.0 \\
0.5\end{array}$ & $\begin{array}{l}13,940 \pm 140 \\
11,670 \pm 100\end{array}$ \\
\hline $131-133$ & 10.4 & $\begin{array}{l}\text { G sacculifera } \\
P \text { obliquiloculata }\end{array}$ & $\begin{array}{l}2.7 \\
0.4\end{array}$ & $\begin{array}{l}20,670 \pm 200 \\
21,060 \pm 220\end{array}$ \\
\hline $141-142$ & 27.2 & $\begin{array}{l}\text { G sacculifera } \\
P \text { obliquiloculata }\end{array}$ & $\begin{array}{l}3.6 \\
0.7\end{array}$ & $\begin{array}{l}19,220 \pm 200 \\
18,750 \pm 170\end{array}$ \\
\hline
\end{tabular}

biases acts in only one direction. For example, were secondary calcification responsible, the ages would be shifted toward younger values, and were reworking of previously deposited forams the reason, the ages would be shifted toward older values. These extreme interpretations are shown in Figure 1.

Oxygen isotope results (see Fig 2) on G sacculifera (Oppo \& Fairbanks, pers commun) and on $G$ ruber and benthics (Lindsley et al, 1985) show that

TABLE 2

${ }^{14} \mathrm{C}$ ages on western Pacific core V33-88 (2 $\left.42^{\prime} \mathrm{N}, 127^{\circ} 50^{\prime} \mathrm{E}, 3237 \mathrm{~m}\right)$

\begin{tabular}{|c|c|c|c|}
\hline $\begin{array}{l}\text { Depth } \\
\text { (cm) }\end{array}$ & Method & Material & $\begin{array}{l}{ }^{14} \mathrm{C} \text { age } \\
(\mathrm{yr})\end{array}$ \\
\hline $0-6$ & $\begin{array}{l}\text { Decay* } \\
\text { LDGO }\end{array}$ & Bulk $\mathrm{CaCO}_{3}$ & $1,700 \pm 150$ \\
\hline $28-32$ & $\begin{array}{l}\text { Decay* } \\
\text { LDGO }\end{array}$ & Bulk $\mathrm{CaCO}_{3}$ & $3,900 \pm 150$ \\
\hline $50-52$ & $\begin{array}{l}\text { Decay* } \\
\text { LDGO }\end{array}$ & Bulk $\mathrm{CaCO}_{3}$ & $5,510 \pm 200$ \\
\hline $102-110$ & $\begin{array}{l}\text { Decay* } \\
\text { LDGO }\end{array}$ & Bulk $\mathrm{CaCo}_{3}$ & $11,050 \pm 400$ \\
\hline $126-132$ & $\begin{array}{l}\text { Decay* } \\
\text { LDGO }\end{array}$ & Bulk $\mathrm{CaCO}_{3}$ & $12,600 \pm 500$ \\
\hline \multirow[t]{2}{*}{$135-136$} & $\begin{array}{l}\text { AMS } \\
\text { Zürich }\end{array}$ & Gruber & $13,040 \pm 110$ \\
\hline & $\begin{array}{l}\text { AMS } \\
\text { Zürich }\end{array}$ & Pobliquiloculata & $13,360 \pm 140$ \\
\hline \multirow[t]{2}{*}{$155-156$} & $\begin{array}{l}\text { AMS } \\
\text { Zürich }\end{array}$ & Gruber & $14,270 \pm 120$ \\
\hline & $\begin{array}{l}\text { AMS } \\
\text { Zürich }\end{array}$ & Pobliquiloculata & $14,310 \pm 150$ \\
\hline
\end{tabular}
(LDGO) 


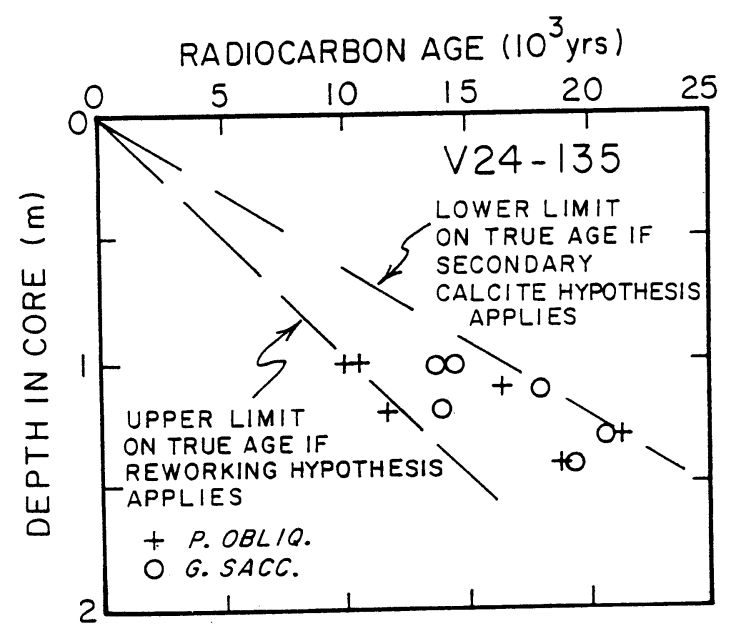

Fig 1. Plot of ${ }^{14} \mathrm{C}$ age $v s$ depth in Sulu Sea core V24-135. The dashed lines show limits on the true age $v s$ depth trend if, on the one hand, reworking ( $i e$, resuspension coupled with latthe true age $v s$ depth trend if, on the one hand, and on the other, secondary calcite deposition is the cause of the scatter in the ages.

planktonic shells from the $100 \mathrm{~cm}$ level have glacial oxygen isotope ratios. The youngest age that shells with full glacial $\delta^{18} \mathrm{O}$ could have is ca 13,000 yr. This suggests that the $\simeq 14,000$-yr age for $G$ sacculifera from the $101-$ $102 \mathrm{~cm}$ horizon is to be preferred over the $\simeq 10,400$-yr age for $P$ obliquiloculata. If this logic is accepted, then we would have to conclude that the villain is a process such as secondary calcite deposition, which lowers the age of the calcite. If so, then all the ages in Table 1 are lower limits. However, it is also possible that resuspension of old foraminifera shells (coupled with lateral transport) created this hodge-podge of ages. However, the $P$ obliquiloculata age of $10,400 \mathrm{yr}$ at $101-102 \mathrm{~cm}$ and of $11,700 \mathrm{yr}$ for the $121-122 \mathrm{~cm}$ horizon appear to be inexplicable if reworking is the major factor.

\section{EQUATORIAL PACIFIC CORE V33-88}

Fortunately, the disaster of the Sulu Sea was not repeated for core V33-38 from the equatorial Pacific (see Fig 3). This core, chosen because reconnaissance ${ }^{14} \mathrm{C}$ measurements made by the conventional decay counting method showed it to have a high deposition rate, yielded concordant $G$ ruber and $P$ obliquiloculata ages. Unfortunately, this core had too few $G$ sacculifera to permit measurement, hence, the substitution of $G$ ruber. Also, benthics are so rare so that we could not be able to use this otherwise very promising core in our attempt to document the surface to deep ${ }^{14} \mathrm{C} / \mathrm{C}$. ratio difference for the glacial Pacific.

\section{CONCLUSIONS}

Our purpose in publishing this note is to emphasize that high deposition rate cores are full of surprises. Table 3 presents a summary of the AMS ${ }^{14} \mathrm{C}$ results on 14 high deposition rate cores made by our group and by JC 

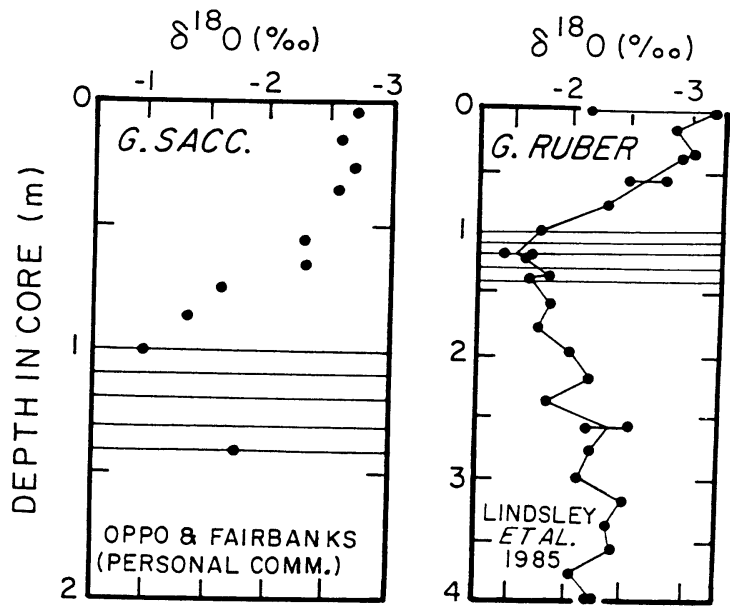

Fig 2. Plots of $\delta^{18} \mathrm{O}$ vs depth for planktonic foraminifera from core V24-135. The levels at which samples were picked for ${ }^{14} \mathrm{C}$ analysis are shown by horizontal lines.

Duplessy and coworkers at the Gif-sur-Yvette Tandetron AMS Facility in France. In one core we have studied and one the French have studied a hiatus exists. In one core we have studied and in one core the French have studied an age reversal is found. In four cores we have studied unexplainable differences between coexisting planktonic foraminifera have been found. None of these deficiencies would have been picked up by conventional methods ( $i e$, lithology, fauna and stable isotope) of studying deep-sea cores. AMS ${ }^{14} \mathrm{C}$ measurements are revealing that, at least in areas of high deposition rate, the assumptions of ideal accumulation and preservation often do not apply.

On the other hand, cores have been found which do appear to fulfill

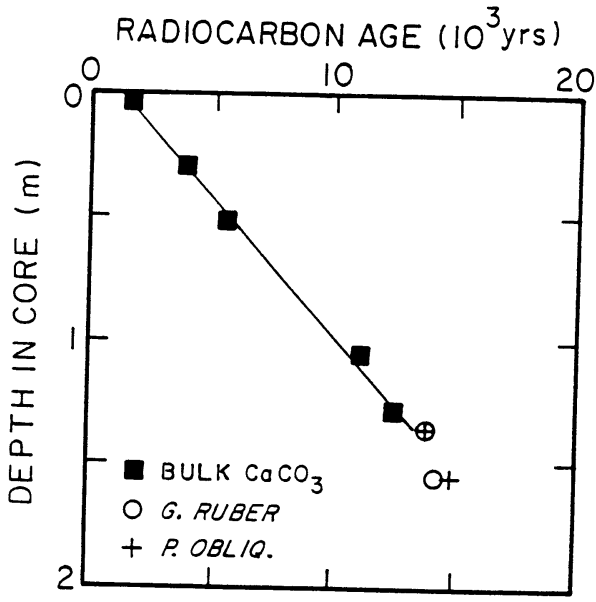

Fig $3 .{ }^{14} \mathrm{C}$ age vs depth in core V33-88 from the western equatorial Pacific. 


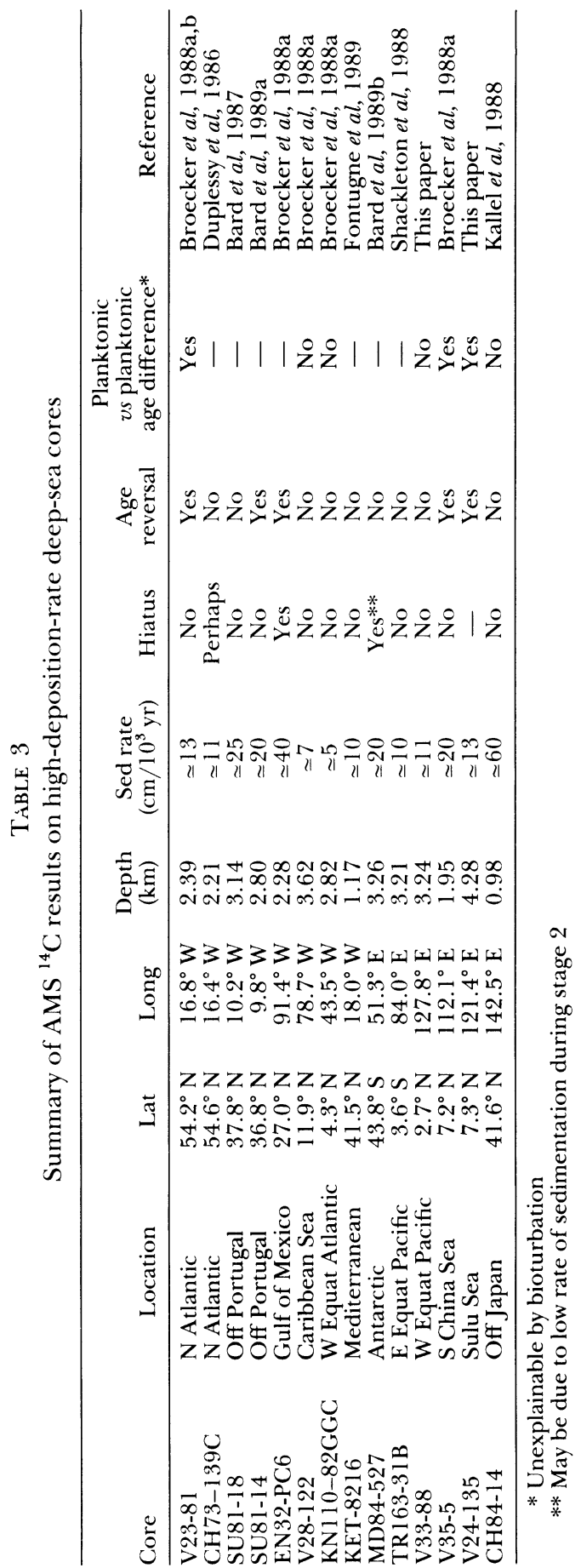


our expectations. Cores in which coexisting planktonics yield concordant ages and smooth age $v$ depth profiles are as common as those containing anomalies. Unfortunately, to find one such good core we may have to look at and discard one which is subject to disturbance. The message of the results now in hand is that where accurate chronologies are required, it is necessary to prove the validity of the core by making ${ }^{14} \mathrm{C}$ measurements on more than one species of planktonic foraminifera and by making detailed down-core ${ }^{14} \mathrm{C}$ age profiles.

\section{ACKNOWLEDGMENTS}

Discussions with Edouard Bard proved helpful in preparing Table 3. Funds for this research were provided by NSF grant ATM86-05372 and NASA grant NAGW 895, LDGO contribution \#4509.

\section{REFERENCES}

Bard, E, Arnold, M, Maurice, P, Duprat, J, Moyes, J and Duplessy, J C, 1987, Retreat velocity of the North Atlantic polar front during the last deglaciation determined by ${ }^{14} \mathrm{C}$ accelerator mass spectrometry: Nature, v 328, p 791-794.

Bard, E, Fairbanks, R, Arnold, M, Maurice, P, Duprat, J, Moyes, J and Duplessy, J-C, 1989a Sea-level estimates during the last deglaciation based on $\delta^{18} \mathrm{O}$ and accelerator mass spectrometry ${ }^{14} \mathrm{C}$ ages measured in Globigerina bulloides: Quaternary Research, v 31, p 381391.

Bard, E, Labeyrie, L, Arnold, M, Labracherie, M, Pichon, J-J, Duprat, J and Duplessy, J-C, $1989 \mathrm{~b}$, AMS $-{ }^{14} \mathrm{C}$ ages measured in deep sea cores from the Southern Ocean oceanographic and stratigraphic uncertainties: Quaternary Research, v 31, p 309-317.

Broecker, W S, Andrée, M, Bonani, G, Mix, A, Klas, M, Wolfli, W and Oeschger, H, 1988a, Comparison between the radiocarbon ages of coexisting planktonic foraminifera: Paleoceanog, v 3, p 647-658.

Broecker, W S, Andrée, M, Wölfli, W, Oeschger, H, Bonani, G, Kennett, J and Peteet, D, $1988 \mathrm{~b}$, The chronology of the last deglaciation: Implications to the cause of the Younger Dryas event: Paleoceanog, v 3, p 1-19

Duplessy, J C, Arnold, M, Maurice, P, Bard, E, Duprat, J and Moyes, J, 1986, Direct dating of the oxygen-isotope record of the last deglaciation by ${ }^{14} \mathrm{C}$ accelerator mass spectrometry: Nature, v 320, p 350-352.

Fontugne, M R, Paterne, M, Calvert, S E, Murat, A, Guichard, F and Arnold, M, 1989, Adriatic deep water formation during the Holocene: Implication for the reoxygenation of the deep Eastern Mediterranean Sea: Paleoceanog, v 4, no. 2, p 199-206.

Kallel, N, Labeyrie, L D, Arnold, M, Okada, H, Dudley, W C and Duplessy, J-C, 1988, Evidence of cooling during the Younger Dryas in the western North Pacific: Oceanolog Acta, v 11, p 369-375.

Lindsley, B K, Thunell, R, Morgan C and Williams, D F, 1985, Oxygen minimum expansion in the Sulu Sea, western equatorial Pacific, during the last glacial low stand of sea level: Marine Micropaleontol, $v 9$, p 395-418.

Shackleton, N J, Duplessy, J-C, Arnold, M, Maurice, P, Hall, M and Cartlidge, J, 1988, Radiocarbon age of Last Glacial Pacific deep water: Nature, v 335, p 708-711.

Vogel, J S, Southon, J R and Nelson, D E, 1987, ${ }^{14} \mathrm{C}$ background levels in an Accelerator Mass Spectrometer system: Radiocarbon, v 29, no. 3, p 323-333. 